$\odot$

\title{
JACQUES GALÉOT
}

ET

\section{LA RÉPUBLIQUE DE VENISE}

\author{
PAR \\ P.-M. PERRET.
}

Extrait de la Bibliothèque de l'École des chartes, Année 1891, t. LII.

PARIS

1892 